\title{
Unlocking the Catalytic Hydrogenolysis of Chlorosilanes into Hy- drosilanes with Superbases
}

\author{
Gabriel Durin, Jean-Claude Berthet, Emmanuel Nicolas, and Thibault Cantat* \\ Université Paris-Saclay, CEA, CNRS, NIMBE, 91191 Gif-sur-Yvette Cedex, France \\ KEYWORDS: Hydrosilane synthesis, hydrogenolysis, homogenous catalysis, superbases, iridium pincer complex
}

\begin{abstract}
The efficient synthesis of hydrosilanes by catalytic hydrogenolysis of chlorosilanes is described, using an iridium (III) pincer catalyst. A careful selection of a nitrogen base (incl. sterically hindered guanidines and phosphazenes) can unlock the preparation of $\mathrm{Me}_{3} \mathrm{SiH}, \mathrm{Et}_{3} \mathrm{SiH}$ and $\mathrm{Me}_{2} \mathrm{SiHCl}$ in high yield (up to 98\%), directly from their corresponding chlorosilanes.
\end{abstract}

Hydrosilanes are useful molecules in the industry for the production of a variety of organosilicon compounds through hydrosilylation of alkenes or dehydrocoupling reactions. ${ }^{1,2}$ In organic synthesis, these mild reducing agents promote reactions with high selectivity and efficiency such as reduction of esters into aldehydes ${ }^{3}$ or ethers ${ }^{4}$ and amides into amines or enamines. ${ }^{5,6}$ Where the use of hydrogen as a reductive source suffers from thermodynamic limitations, ${ }^{7}$ hydrosilanes provide convenient alternatives and recent studies have highlighted new utilizations to recover catalytically the valuable organic content of oxygenated feedstocks (lignin, plastics and $\mathrm{CO}_{2}$ ) through $\mathrm{C}-$ $\mathrm{O}$ bond reduction or to develop phosphine-catalyzed Wittig reactions. ${ }^{8}$ However, hydrosilanes are produced via energy intensive processes and their utilization also generates quantities of siloxanes. ${ }^{9}$ The recycling of these wastes begins with an acidic treatment $(\mathrm{HCl})$ to provide chlorosilanes which are key intermediates in the synthetic route to hydrosilanes. ${ }^{10}$ At that time, the most used reagents to reduce [Si]- $\mathrm{Cl}$ bonds in chlorosilanes are anionic metal hydrides, such as $\mathrm{LiAlH}_{4}$ (Scheme 1). ${ }^{11}$ The catalytic conversion of [Si]- $\mathrm{Cl}$ into $[\mathrm{Si}]-\mathrm{H}$ derivatives using dihydrogen as reductive source remains highly challenging.

Catalytic hydrogenolysis of halosilanes and triflates was recently introduced by Shimada et al. in 2017 and Schneider et al. in 2018 (Scheme 1). They reported the efficient transformation of $\mathrm{R}_{3} \mathrm{SiX}$ ( $\mathrm{X}=\mathrm{OTf}, \mathrm{I}, \mathrm{Br}$ ) into $\mathrm{R}_{3} \mathrm{SiH}$ under dihydrogen with the use of noble transition metal catalysts, in the presence of a nitrogen base to drive the thermodynamics of the transformation. This reaction is however particularly difficult with chlorosilanes because the $\mathrm{Si}-\mathrm{Cl}$ is much stronger than the $\mathrm{Si}-$ $\mathrm{Br}$ and $\mathrm{Si}-\mathrm{I}$ bonds, with bond dissociation energies of 456, 343, and $339 \mathrm{~kJ} \mathrm{~mol}^{-1}$, respectively. ${ }^{12}$ As such, a single example supplied the direct hydrogenolysis of $\mathrm{Me}_{3} \mathrm{SiCl}$ into $\mathrm{Me}_{3} \mathrm{SiH}$ but in a near stoichiometric yield $(7 \%) .{ }^{13}$ To tackle these limitations, before initiating catalytic hydrogenolysis in presence of a base, a chloride abstractor such as $\mathrm{NaI}$ or $\mathrm{Na}\left[\mathrm{B}\left(\mathrm{C}_{6} \mathrm{H}_{3}-3,5-\left(\mathrm{CF}_{3}\right)_{2}\right)_{4}\right]$ was first added, which greatly improved the yields in hydrosilane (up to $84 \%$ ). ${ }^{13,14}$ We present here an efficient catalytic hydrogenolysis of chlorosilanes into hydrosilanes using an iridium (III) pincer catalyst. This novel route, based on the careful choice of the base (guanidine or phosphazene), avoids the use of additional additives and enables the formation of $\mathrm{Me}_{3} \mathrm{SiH}$, $\mathrm{Me}_{2} \mathrm{SiHCl}$ and $\mathrm{Et}_{3} \mathrm{SiH}$ in yields up to $98 \%$.

$$
\begin{aligned}
& \text { Metal hydride reduction } \\
& \qquad \mathrm{R}_{4-n} \mathrm{SiCl}_{n}+2 \mathrm{n} \mathrm{M}\left[\mathrm{EH}_{4}\right] \longrightarrow \mathrm{R}_{4-n} \mathrm{SiH}_{n}+2 \mathrm{nMCl}+\mathrm{nEH}_{3} \begin{array}{l}
\mathrm{M}=\mathrm{Li}, \mathrm{Na} \\
\mathrm{E}=\mathrm{Al}, \mathrm{B}
\end{array}
\end{aligned}
$$

Hydrogenolysis of SiX bonds

Shimada, 2017 and Schneider, 2018:

$$
\begin{aligned}
& \mathrm{R}_{4-\mathrm{n}} \mathrm{SiX}_{\mathrm{n}} \frac{[\mathrm{Ir}] \text { or }[\mathrm{Ru}], \mathrm{H}_{2} \text { (4 bar) }}{{ }^{i} \mathrm{Pr}_{2} \mathrm{NEt}_{\text {or }} \mathrm{NEt}_{3}} \\
& \mathrm{X}=\mathrm{OTf}, \mathrm{I}, \mathrm{Br}, \mathrm{BAr}^{\mathrm{F}} \\
& \text { no reaction for } \mathrm{X}=\mathrm{Cl}
\end{aligned}
$$

$\mathrm{R}_{4-n} \mathrm{SiH}_{\mathrm{n}}$
up to $95 \%$ up to $95 \%$
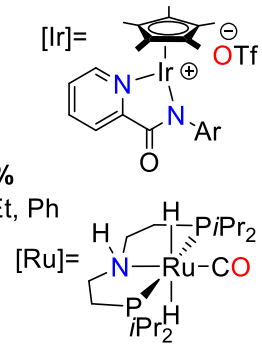

This work: Hydrogenolysis of $\mathrm{SiCl}$ bonds
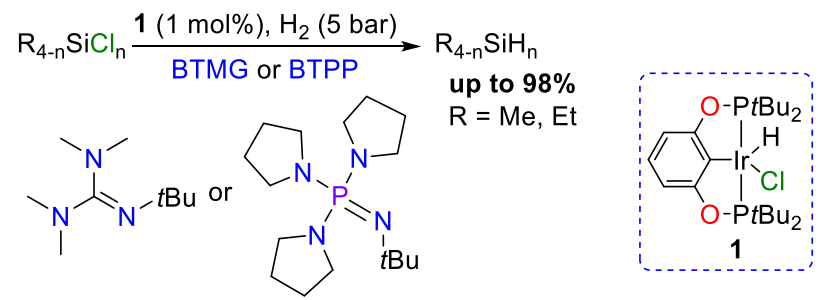

Scheme 1. Different synthetic ways from chlorosilanes to hydrosilanes.

The hydrogenolysis of silyl halides into hydrosilanes is thermodynamically unfavoured and, as shown in Scheme 1, requires a base, to form the corresponding ammonium salt as a byproduct and overcome the thermodynamic limitations. Schneider et al. have computed that trialkylamines are not basic enough to perform the hydrogenolysis of chlorosilanes with their $\mathrm{Ru}(\mathrm{II})$ complex and a stoichiometric amount of additives was needed with $\mathrm{NEt}_{3}$ or $i \mathrm{Pr}_{2} \mathrm{NEt}$ to induce the reaction (Scheme 1). ${ }^{14}$ We chose iridium(III) pincer complexes as potential catalysts because they are competent in a number of hydrogenation ${ }^{15}$ or hydrosilylation ${ }^{16}$ reactions with formation of reactive [Ir]-H entities which transfer hydrides readily.

We thus turned to the precursor $\left.\left[\operatorname{Ir}\left({ }^{t \mathrm{Bu}} \mathrm{POCOP}\right) \mathrm{HCl}\right]\right]^{17}(\mathbf{1}){ }^{t \mathrm{Bu}-}$ POCOP $\left.=\left(\mathrm{C}_{6} \mathrm{H}_{3}\right)\left\{1,3-\mathrm{OP} t \mathrm{Bu}_{2}\right\}_{2}\right)$ as a possible catalyst for the $\mathrm{Si}-\mathrm{X}$ to $\mathrm{Si}-\mathrm{H}$ transformation. Beyond its thermodynamic role, the base is kinetically determinant to favour the formation of a metal hydride intermediate from a metal chloride and $\mathrm{H}_{2}$ 
(Scheme 2). The choice of the base is thus crucial and must be rationalized. Organic superbases such as amidines, guanidines and phosphazenes are neutral bases, stronger than alkylamines, and are well-known activators in a variety of base mediated organic transformations as well as in catalysis. ${ }^{18}$ Hydroxide or alkoxide bases are not compatible with chlorosilanes and a series of six neutral bases $\left(\mathrm{NEt}_{3}, \quad \mathrm{DBU}=1,8\right.$ diazabicyclo[5.4.0] undec-7-ene, $\quad \mathrm{TBDH}=1,5,7-$ triazabicyclo[4.4.0]dec-5-ene, $\quad$ MeTBD = 7-methyl-1,5,7triaza-bicyclo[4.4.0]dec-5-ene, $\quad \mathrm{BTMG}=2-t \mathrm{Bu}-1,1,3,3-$ tetramethyl-guanidine, $\mathrm{BTPP}=(t \mathrm{Bu}-$ imino)tri(pyrrolidino)phosphorane) differing by their Brønsted basicity $\left(p \mathrm{~K}_{\mathrm{a}}\right)$ and steric hindrances have thus been considered in this work.

The role of the base was evaluated in the catalytic hydrogenolysis of $\mathrm{Me}_{3} \mathrm{SiCl}$ ( 5 bar of $\mathrm{H}_{2}$, room temperature, in benzene) with $1(1 \mathrm{~mol} \%)$ (Eqn 1). In the presence of $\mathrm{NEt}_{3}$, no reaction occurred even after $48 \mathrm{~h}$ (Table 1 , entry 1). While Shimada et al. observed, by using an $\operatorname{Ir}(\mathrm{I})$ complex and DBU, the near stoichiometric formation of $\mathrm{Me}_{3} \mathrm{SiH}$ with a TON of 1.4 with DBU after 7 days ${ }^{13} 1$ provided $\mathrm{Me}_{3} \mathrm{SiH}$ in a promising $6 \%$ yield (TON=6) after $18 \mathrm{~h}$ (Eqn 1, entry 2). TBDH proved ineffective and reacted immediately with $\mathrm{Me}_{3} \mathrm{SiCl}$ to give a white precipitate of the silylium adduct [ $\left.\mathrm{TBDHSiMe}_{3}\right] \mathrm{Cl}$ (Scheme 2, right). In contrast to what previously reported, ${ }^{13}$ here, the formation of this silylium [BaseSiMe $\mathrm{BCl}_{3} \mathrm{Cl}$ did not increase the reactivity of the chlorosilane as it remained inert even after $48 \mathrm{~h}$ at $90^{\circ} \mathrm{C}$ in benzene (Table 1, entry 3 ). This result was further supported by calculations (vide infra). Even in $\mathrm{CD}_{2} \mathrm{Cl}_{2}$ where [TBDHSiMe $\left.\mathrm{TB}_{3}\right] \mathrm{Cl}$ is soluble and formed as major product, only traces of $\mathrm{Me}_{3} \mathrm{SiH}$ were detected (Table 1, entry 4). Interestingly, $\mathrm{Me}_{3} \mathrm{SiH}$ was obtained in $25 \%$ yield after $18 \mathrm{~h}$ (Table 1, entry 5) with the use of MeTBD. Using BTMG and BTPP superbases, yields in $\mathrm{Me}_{3} \mathrm{SiCl}$ were considerably improved, up to $54 \%$ after $18 \mathrm{~h}$ (Table 1, entries 6 and 7). These results represent the first efficient generation of a hydrosilane by hydrogenolysis of a chlorosilane derivative, without an activator. As the BTPP base is relatively expensive, its recycling would be appealing. A solution might come from electrodialysis to recover the BTMG or BTPP bases from their corresponding hydrogen chloride salt, a process which has been successfully applied to generate ammonia from ammonium chloride. ${ }^{19}$

In contrast to $\mathrm{TBDH}$, the silylium adducts $\left[\mathrm{BaseSiMe}_{3}\right] \mathrm{Cl}$ were not formed in benzene with the bases MeTBD, BTMG, and BTPP, while the hydrogenolysis by-product [Base $\mathrm{H}] \mathrm{Cl}$ deposited gradually, except for [BTPPH] $\mathrm{Cl}$ which is soluble in benzene. Decreasing the $\mathrm{H}_{2}$ pressure to 1 bar somewhat decreased the conversion of $\mathrm{Me}_{3} \mathrm{SiCl}(23 \%)$ and the yield in $\mathrm{Me}_{3} \mathrm{SiH}$ (18\% after $18 \mathrm{~h}$ ) (Table 1 , entry 8$) .{ }^{13,14}$ These experiments underline the crucial role of the base which must be as strong as DBU to favour hydrogenolysis. The ability of the above bases to favour either the hydrogenolysis process or a nucleophilic substitution on $\mathrm{Me}_{3} \mathrm{SiCl}$ was correlated with thermodynamic DFT calculations (Scheme 3). Gibbs free energies (in kcal.mol $\left.{ }^{-1}\right) \Delta \mathrm{G}_{1}$ for hydrogenolysis (in purple) and $\Delta \mathrm{G}_{2}$ for nucleophilic substitution (in orange) were computed at the PBE0D3/6-311+G(d,p) level of theory, using the SMD model solvation model in benzene (see SI page S21 for details).

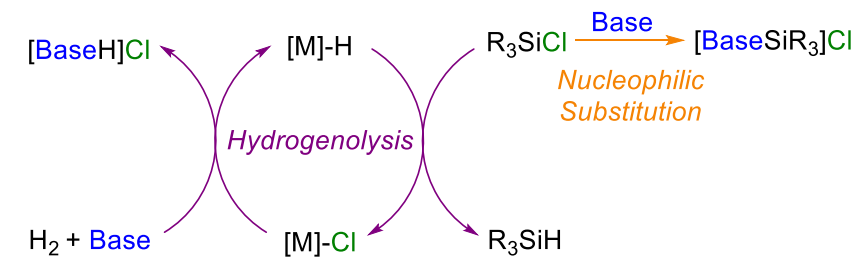

Scheme 2. Proposed mechanism for the catalytic hydrogenolysis of silyl chlorides and nucleophilic substitution.

Table 1. Screening of bases for the hydrogenolysis of $\mathrm{Me}_{3} \mathrm{SiCl}$ in $\mathrm{C}_{6} \mathrm{D}_{6}$ with 1. $^{a}$

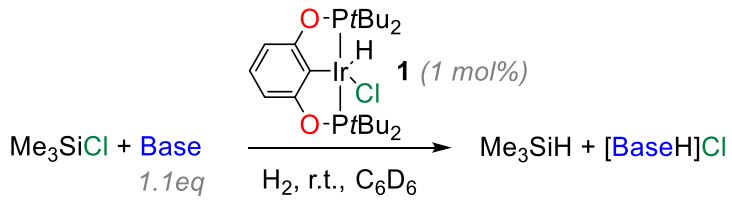

\begin{tabular}{|l|l|l|l|l|l|l|}
\hline $\begin{array}{l}\text { En- } \\
\text { try }\end{array}$ & $\begin{array}{l}\mathrm{H}_{2} \\
\text { pres- } \\
\text { sure } \\
(\text { bar })\end{array}$ & Base & $p \mathrm{~K}_{\mathrm{a}}{ }^{c}$ & $\begin{array}{l}\text { Conver- } \\
\text { sion }^{b} \\
(\%)\end{array}$ & $\begin{array}{l}\text { Yield (Se- } \\
\text { lectivity })^{b} \\
(\%)\end{array}$ & $\begin{array}{l}\text { Reac- } \\
\text { tion } \\
\text { Time } \\
(\mathrm{h})\end{array}$ \\
\hline 1 & 5 & $\mathrm{NEt}_{3}$ & 18.8 & 0 & $0(0)$ & 48 \\
\hline 2 & 5 & DBU & 24.3 & 10 & $6(60)$ & 18 \\
\hline 3 & 5 & TBDH & 26.0 & 0 & $0(0)$ & 48 \\
\hline $4^{\text {d }}$ & 5 & TBDH & 26.0 & 1 & $<1$ & 18 \\
\hline 5 & 5 & MeTBD & 25.5 & 30 & $25(83)$ & 18 \\
\hline 6 & 5 & BTMG & 26.5 & 55 & $42(76)$ & 18 \\
\hline 7 & 5 & BTPP & 28.4 & 59 & $54(92)$ & 18 \\
\hline 8 & 1 & BTPP & 28.4 & 23 & $18(78)$ & 18 \\
\hline
\end{tabular}

${ }^{a}$ General conditions: $0.1 \mathrm{mmol}$ of $\mathrm{Me}_{3} \mathrm{SiCl}, 0.11 \mathrm{mmol}$ of base, $1 \mu \mathrm{mol}$ of catalyst, $0.6 \mathrm{~mL}$ of solvent, at room temperature under 5 bar $\mathrm{H}_{2}$ except entry 7 ( 1 bar). ${ }^{b}$ Conversions, selectivities, and yields were determined by ${ }^{1} \mathrm{H}$ NMR spectroscopy, through integration of the $\mathrm{R}_{3} \mathrm{Si}$ signals versus an internal standard (1,3,5-trimethylbenzene). ${ }^{c} \mathrm{pKa}$ in $\mathrm{MeCN}^{20}$. ${ }^{d}$ in $\mathrm{CD}_{2} \mathrm{Cl}_{2}$.

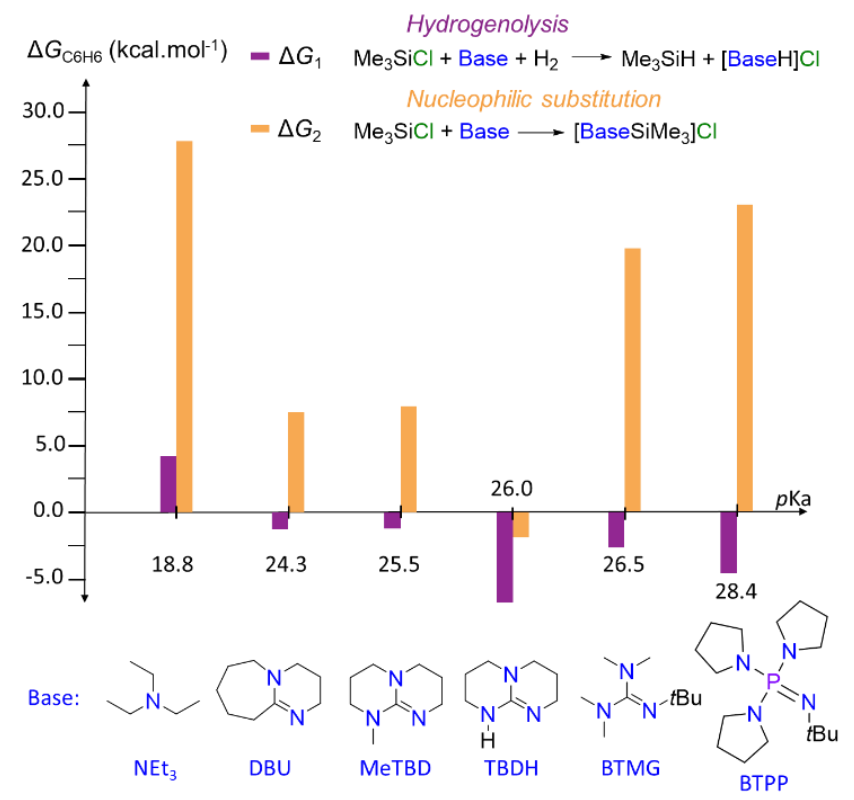


Scheme 3. Calculated $\Delta \mathbf{G}_{\mathrm{C} 6 \mathrm{H} 6}$ by DFT (PBE0-D3/6311+G(d,p), SMD: benzene) of the hydrogenolysis process $\mathrm{Me}_{3} \mathrm{SiCl}+\mathrm{H}_{2}+\mathrm{Base} \rightarrow \mathrm{Me}_{3} \mathrm{SiH}+[\mathrm{BaseH}] \mathrm{Cl}\left(\Delta \mathrm{G}_{1}\right)$ and the reaction $\mathrm{Me}_{3} \mathrm{SiCl}+$ Base $\rightarrow[$ BaseSiMe $]$ Cl $\left(\Delta \mathrm{G}_{2}\right)$ plotted against the $p K_{a}$ of the base in MeCN.

The highest positive $\Delta \mathrm{G}$ values are found for the amine $\mathrm{NEt}_{3}$ in agreement with the absence of reactivity noted experimentally. Increasing the Brønsted basicity of the base favours the hydrogenolysis of $\mathrm{Me}_{3} \mathrm{SiCl}$ as reflected in the drop of $\Delta G_{1}$ from -1.2 to $-4.6 \mathrm{kcal}^{\mathrm{mol}}{ }^{-1}$ from DBU to BTPP. While the hydrogenolysis of chlorosilanes $\left(\Delta \mathrm{G}_{1}\right)$ with DBU and MeTBD is only slightly exergonic ( -1.2 and $-1.1 \mathrm{kcal}^{\mathrm{mol}}{ }^{-1}$ respectively), the reaction proceeds in benzene as it is driven by the precipitation of the by-product salt $[\mathrm{BaseH}] \mathrm{Cl}$. Interestingly, with $\mathrm{DBU}$, MeTBD, BTMG and BTPP, formation of the silylium [BaseS$\left.\mathrm{iMe}_{3}\right] \mathrm{Cl}$ is disfavoured with $\Delta \mathrm{G}_{2}$ values ranging from +7.6 to $+23.4 \mathrm{kcal}^{\mathrm{mol}}{ }^{-1}$, presumably due to unfavourable steric interactions. TBDH exhibits a very different behaviour: the two reactions being thermodynamically favourable, the more negative value of $\Delta \mathrm{G}_{1}$ may be related to the high stability of $\left[\mathrm{TBDH}_{2}\right] \mathrm{Cl}^{21}$ However, the absence of $\mathrm{Me}_{3} \mathrm{SiH}$ production in the presence of TBDH therefore results either from the lower $\Delta \mathrm{G}_{2}$ balance compared to $\Delta \mathrm{G}_{1}$ or the low solubility of $\left[\mathrm{TBDHSiMe}_{3}\right] \mathrm{Cl}$ which was observed to rapidly precipitate in $\mathrm{C}_{6} \mathrm{D}_{6}$.

Experimental and computational results show that BTPP is the most suitable base for the production of $\mathrm{Me}_{3} \mathrm{SiH}$ because it presents a large $\Delta \mathrm{G}_{1}-\Delta \mathrm{G}_{2}$ difference with a negative $\Delta \mathrm{G}_{1}$ value of $-4.6 \mathrm{kcal} . \mathrm{mol}^{-1}$, and it is able to favour the thermodynamics of the hydrogenolysis while preventing the formation of the silylium side-product $\left[\mathrm{BaseSiMe}_{3}\right] \mathrm{Cl}$. Since the formation of the hydrogenolysis by-product $[\mathrm{Base} \mathrm{H}] \mathrm{Cl}$ can drive the catalysis and because its solubility is strongly related to the nature of the solvent, we investigated the influence of some polar and nonpolar solvents in the hydrogenolysis of $\mathrm{Me}_{3} \mathrm{SiCl}$ (1-5 bar $\mathrm{H}_{2}$, r.t., $18 \mathrm{~h}$ ), catalyzed by $1(1 \mathrm{~mol} \%)$ in the presence of BTPP (Eqn 2, Table 2). Replacing benzene with toluene or THF, at 1 bar of $\mathrm{H}_{2}$, somewhat decreased the yields in $\mathrm{Me}_{3} \mathrm{SiH}$ to 13 and $17 \%$, respectively (Table 2, entries 2 and 3). In the more polar solvents DMF, DMSO and MeCN, the conversion rates at 1 bar $\mathrm{H}_{2}$ are low and $\mathrm{Me}_{3} \mathrm{SiH}$ is observed only in $\mathrm{MeCN}$ and in low quantity $(4 \%)$ (Table 2 , entries 6-8). NMR analyses actually revealed in the later solvents the formation of large quantities of the soluble silylium salt [BTPPSiMe 3 ]Cl, which is detrimental to the catalysis. Finally, at 1 bar $\mathrm{H}_{2}$, the highest conversion $(56 \%)$ with excellent yield and selectivity in $\mathrm{Me}_{3} \mathrm{SiH}(56 \%$ and $99 \%$ respectively) were achieved in dichloromethane (entry 4). Importantly, under 5 bar $\mathrm{H}_{2}, \mathrm{Me}_{3} \mathrm{SiH}$ was obtained in near quantitative yield (98\%) from $\mathrm{Me}_{3} \mathrm{SiCl}$ (entry 5).

Capitalizing on these findings, the hydrogenolysis of $\mathrm{Et}_{3} \mathrm{SiCl}$ and $\mathrm{Me}_{2} \mathrm{SiCl}_{2}$ was attempted (Scheme 4; Eqns 3-5). The conversion of $\mathrm{Et}_{3} \mathrm{SiCl}$ with $\mathrm{BTPP}$ proved more difficult than $\mathrm{Me}_{3} \mathrm{SiCl}$ requiring $40 \mathrm{~h}$ to afford $\mathrm{Et}_{3} \mathrm{SiH}$ selectively in $59 \%$ yield. This is in agreement with the observation of the Shimada and Schneider groups, that an increase in the steric hindrance of the silyl iodides or triflates led to longer reaction times. ${ }^{13,14} \mathrm{In}$ terestingly, $\mathrm{Me}_{2} \mathrm{SiCl}_{2}$, which is more electrophilic ${ }^{22}$ than $\mathrm{Me}_{3} \mathrm{SiCl}$, proved less reactive in our conditions (Scheme 4, Eqn 4) and a mixture of $\mathrm{Me}_{2} \mathrm{SiHCl}(13 \%)$ and $\mathrm{Me}_{2} \mathrm{SiH}_{2}(3 \%)$ was observed after $40 \mathrm{~h}$. This result matches the hydrogenolysis of $\mathrm{Me}_{2} \mathrm{Si}(\mathrm{OTf})_{2}$ by an iridium catalyst reported to be much slower
(7 days vs $8 \mathrm{~h}$ for $\mathrm{Me}_{3} \mathrm{SiOTf}$ ). ${ }^{13}$ These poor yields in hydrosilanes demonstrated that the hydrogenolysis of dialkylchlorosilanes must be optimized. Replacing BTPP with MeTBD (Scheme 4, Eqn 5) favoured higher conversion rate in $\mathrm{Me}_{2} \mathrm{SiCl}_{2}(48 \%)$ and formation of $\mathrm{Me}_{2} \mathrm{SiHCl}$ as the major product (37\% yield). Increased reaction times led to higher yields in $\mathrm{Me}_{2} \mathrm{SiHCl}$ (54\% after 7 days). No trace of the silylium [MeTBDSiClMe $\left.{ }_{2}\right] \mathrm{Cl}$ could be detected by ${ }^{1} \mathrm{H}$ NMR in dichloromethane. The latter results evidence the formation of $\mathrm{R}_{2} \mathrm{SiHCl}$ species from $\mathrm{R}_{2} \mathrm{SiCl}_{2}$ in smooth conditions while $\mathrm{Me}_{2} \mathrm{SiH}_{2}$ is the major product with strong reducing agents (such as $\left.\mathrm{LiAlH}_{4}\right)^{23}$

Table 2. Influence of the solvent on the hydrogenolysis of $\mathrm{Me}_{3} \mathrm{SiCl}^{a}$

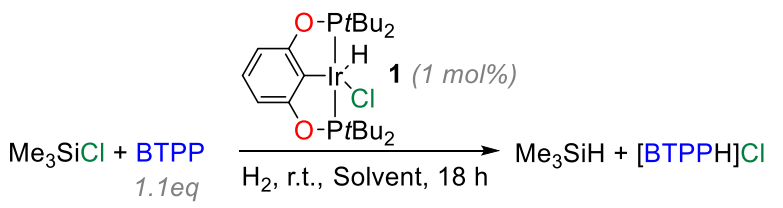

\begin{tabular}{|l|l|l|l|l|l|}
\hline $\begin{array}{l}\text { En- } \\
\text { try }\end{array}$ & $\begin{array}{l}\mathrm{p}\left(\mathrm{H}_{2}\right) \\
(\mathrm{bar})\end{array}$ & Solvent & $\begin{array}{l}\text { Conv. } \\
(\%)\end{array}$ & $\begin{array}{l}\text { Yield } \\
(\text { Select. })^{b} \\
(\%)\end{array}$ & $\varepsilon^{c}$ \\
\hline 1 & 1 & $\mathrm{C}_{6} \mathrm{D}_{6}$ & 23 & $18(78)$ & 2.3 \\
\hline 2 & 1 & Tol- $d_{8}$ & 15 & $13(89)$ & 2.4 \\
\hline 3 & 1 & THF- $d_{8}$ & 17 & $17(99)$ & 7.6 \\
\hline 4 & 1 & $\mathrm{CD}_{2} \mathrm{Cl}_{2}$ & 56 & $56(99)$ & 8.9 \\
\hline 5 & 5 & $\mathrm{CD}_{2} \mathrm{Cl}_{2}$ & 99 & $98(99)$ & 8.9 \\
\hline 6 & 1 & $\mathrm{CD}_{3} \mathrm{CN}$ & 12 & $4(30)$ & 36.6 \\
\hline 7 & 1 & $\mathrm{DMF}-d_{7}$ & 18 & $0(0)$ & 38.3 \\
\hline 8 & 1 & $\mathrm{DMSO}-d_{6}$ & 9 & $0(0)$ & 46.7 \\
\hline
\end{tabular}

${ }^{a}$ General conditions: $0.1 \mathrm{mmol}$ of $\mathrm{Me}_{3} \mathrm{SiCl}, 0.11 \mathrm{mmol}$ of BTPP, $1 \mu \mathrm{mol}$ of 1 ( $1 \mathrm{~mol} \%), 0.6 \mathrm{~mL}$ of solvent, room temperature (r.t.). ${ }^{b}$ Conversions, selectivity and yields were determined by ${ }^{1} \mathrm{H}$ NMR integration of the $\mathrm{Me}_{3} \mathrm{Si}$ signals versus an internal standard (1,3,5trimethylbenzene). ${ }^{c}$ Dielectric constant of the solvents.

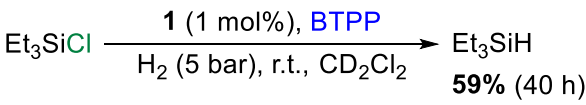

$$
\begin{aligned}
& \mathrm{Me}_{2} \mathrm{SiCl}_{2} \frac{1 \text { (1 mol\%), BTPP }}{\mathrm{H}_{2} \text { (5 bar), r.t., } \mathrm{CD}_{2} \mathrm{Cl}_{2}} \underset{13 \%}{\mathrm{Me}_{2} \mathrm{SiHCl}+\mathrm{Me}_{2} \mathrm{SiH}_{2}} \mathbf{3 \% ( 4 0 \mathrm { h } )}
\end{aligned}
$$

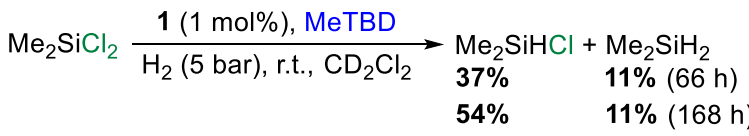

Scheme 4. Catalytic hydrogenolysis by 1 (1 mol\%) of $\mathrm{Et}_{3} \mathrm{SiCl}$ and $\mathrm{Me}_{2} \mathrm{SiCl}_{2}$ with BTMG or MeTBD in $\mathrm{CD}_{2} \mathrm{Cl}_{2}$. Yields were determined by ${ }^{1} \mathrm{H}$ NMR integration of the $\mathrm{R}_{\mathrm{n}} \mathrm{Si}$ $(n=2$ and 3$)$ signals versus an internal standard (1,3,5-trimethylbenzene).

To gain insights into the mechanism of the catalysis in the optimized conditions ( 5 bar $\mathrm{H}_{2}$ in $\mathrm{CH}_{2} \mathrm{Cl}_{2}$ ) (Scheme 5), we focused on the iridium complexes that might form from 1 either by stoichiometric addition of the reagents (Eqn 6,7 and 8) or in catalytic conditions. The ${ }^{1} \mathrm{H}$ NMR spectrum of $\mathbf{1}$ is not modified by addition of 1 equiv. of $\mathrm{Me}_{3} \mathrm{SiCl}$ or $\mathrm{BTPP}$ or when pressurized 
under $\mathrm{H}_{2} . \quad \mathbf{1}$ is however converted in $1 \mathrm{~h}$ into $\left[\operatorname{Ir}\left({ }^{t \mathrm{Bu}-}\right.\right.$ POCOP) $\left.\mathrm{H}_{2}\left(\mathrm{H}_{2}\right)\right]^{24}$ (2) $(81 \%)$, when treated with BTPP under 5 bar $\mathrm{H}_{2} .2$ is the only complex detected by ${ }^{1} \mathrm{H}$ during the catalysis and at its end. Hydrogenolysis of $\mathrm{Me}_{3} \mathrm{SiCl}$ with $\left[\mathrm{Ir}\left({ }^{t \mathrm{Bu}-}\right.\right.$ POCOP $) \mathrm{H}_{2}$ ] (3) $(1 \mathrm{~mol} \%)^{24}$ also led to 2 as the only observable iridium species (see SI Fig. S7). However, $\mathbf{2}$ and $\mathbf{3}$ do not react with stoichiometric quantities of $\mathrm{Me}_{3} \mathrm{SiCl}$ to give $\mathrm{Me}_{3} \mathrm{SiH}$. Our hypothesis for the active species is based on the formation of the anionic hydride species $\left[\mathrm{Ir}\left({ }^{t \mathrm{Bu}} \mathrm{POCOP}\right) \mathrm{H}_{3}\right]^{-}$for which the hydride transfer is expected to be much more efficient than from the neutral derivatives 2 or $\mathbf{3}$ (Eqn 7). Such species are known, $\left[\operatorname{Ir}\left({ }^{t B u} \mathrm{POCOP}\right) \mathrm{H}_{3}\right] \mathrm{Na}^{24}$ was previously reported by Brookhart and co-workers from the treatment of $\mathbf{1}$ with $\mathrm{NaH}$. Although never detected in our catalytic experiments, anionic species may be an intermediate formed by deprotonation of $\mathbf{2}$ with a strong base. Attempts to generate such species from $\mathbf{3}$ using only BTPP and $\mathrm{H}_{2}$ have not been successful. However, the use of a stronger base such as Verkade superbase ${ }^{i \mathrm{Pr}} \mathrm{VB}$ ( ${ }^{\mathrm{P} r} \mathrm{VB}=2,8,9$-Triisopropyl-2,5,8,9-tetraaza-1-phosphabicyclo[3.3.3] undecane) in the presence of $\mathbf{3}$ under $10 \mathrm{bar} \mathrm{H}_{2}$ (Eqn 8 ) in THF immediately afforded a white deposit. This solid has been characterized by NMR in acetonitrile as the ion pair $\left[\operatorname{Ir}\left({ }^{t \mathrm{Bu}-}\right.\right.$ $\left.\mathrm{POCOP}) \mathrm{H}_{3}\right]\left[{ }^{i \mathrm{Pr}} \mathrm{VBH}\right](\mathbf{4})$, featuring both the expected anionic hydride and the phosphonium salt. Complex 4 shows ${ }^{1} \mathrm{H}$ NMR signals similar to those reported in $\left[\operatorname{Ir}\left({ }^{t \mathrm{Bu}} \mathrm{POCOP}\right) \mathrm{H}_{3}\right] \mathrm{Na}^{24}$ It is not stable in $\mathrm{CD}_{2} \mathrm{Cl}_{2},{ }^{25}$ but reacted in $\mathrm{C}_{6} \mathrm{D}_{6}$ with 1 equiv. $\mathrm{Me}_{3} \mathrm{SiCl}$ to give $\mathrm{Me}_{3} \mathrm{SiH}$ quantitatively after $4 \mathrm{~h}$ (Eqn 9). The resulting complexes 3 and $\left[\operatorname{Ir}\left({ }^{t \mathrm{Bu}} \mathrm{POCOP}\right) \mathrm{H}_{2}\left(\mathrm{HSiMe}_{3}\right)\right](\mathbf{5})$ were identified by NMR (Eqn 10 and SI Fig. S17/S18). Complex 5 is analogous to the previously reported $\left[\operatorname{Ir}\left({ }^{t \mathrm{Bu}-}\right.\right.$ POCOP $\left.) \mathrm{H}_{2}\left(\mathrm{HSiEt}_{3}\right)\right]^{26}$ and displays an $\mathrm{Ir}-\mathrm{H}$ hydride signal at $-8.56 \mathrm{ppm}$ by ${ }^{1} \mathrm{H}$ NMR. This result supports the involvement of the anionic hydride complex $\left[\operatorname{Ir}\left({ }^{t B u} \mathrm{POCOP}\right) \mathrm{H}_{3}\right][\mathrm{BTPPH}](6)$ as a key hydride donor in the formation of the hydrosilane. Generated catalytically and prone to reduce $\mathrm{Si}-\mathrm{Cl}$ bonds, complex 6 would be the first anionic trihydride iridium complex involved in catalytic hydrogenation reactions and would be responsible for the excellent performances of this system (Scheme 5).

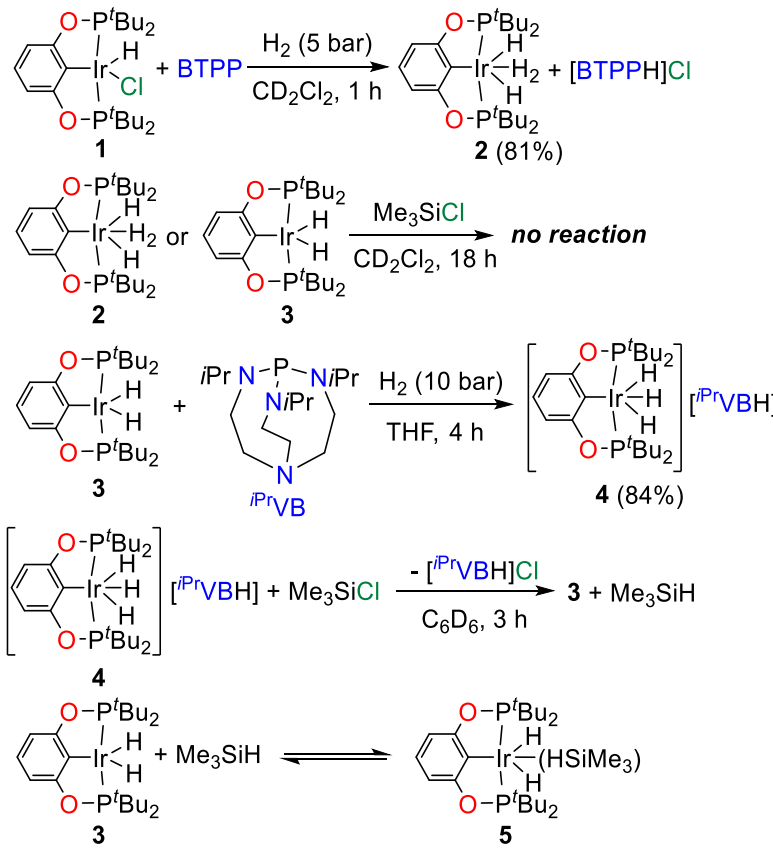

Scheme 5. Stoichiometric reactions. Reaction (7) with 2 has been conducted under 1 bar of $\mathrm{H}_{2}$.

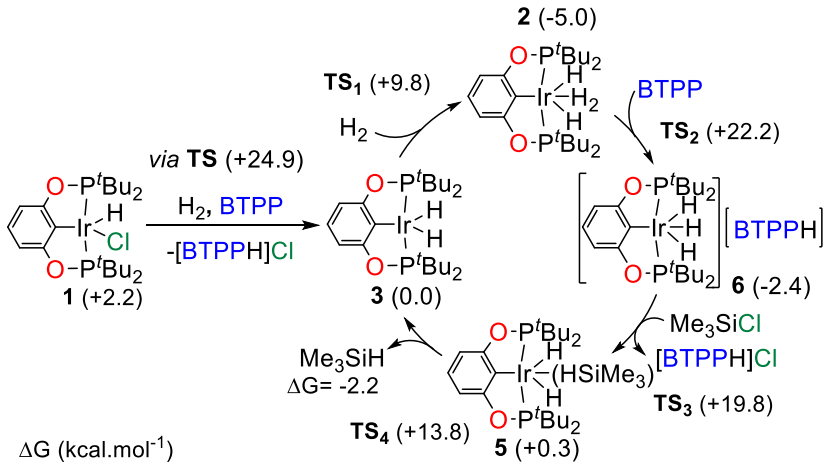

Scheme 6. Computed mechanism (PBE0-D3/Def2-TZVP (Ir), 6-311+G(d,p) (mobile H, Si), 6-31G(d) (other atoms), )//wB97M-V/Def2-TZVPP SMD (Solvent: dichloromethane) for the hydrogenolysis of $\mathrm{Me}_{3} \mathrm{SiCl}$ with $\mathrm{BTPP}$ and 1 or 3. Energies are reported compared to 3, $\mathrm{H}_{2}$, BTPP and $\mathrm{Me}_{3} \mathrm{SiCl}$.

Density functional theory calculations(see SI page S21 for details) were performed to get a deeper insight into the mechanism and to confirm the possible hydride transfer to $\mathrm{Me}_{3} \mathrm{SiCl}$ from the anionic trihydride species $\mathbf{6}$. The most favoured pathway is depicted in Scheme 6: complex $\mathbf{1}$ is a precatalyst and its deprotonation with BTPP under $\mathrm{H}_{2}$ is slightly exergonic $(-2.2$ kcal.mol ${ }^{-1}$ ) and leads to the dihydride species 3 with a high activation barrier at $24.9 \mathrm{kcal}^{\mathrm{mol}} \mathrm{m}^{-1}$ (see SI Fig. S23 for the full computed pathway). 3 is rapidly transformed into $\mathbf{2}$ under $\mathrm{H}_{2}$ $\left(\mathrm{TS}_{1}: \Delta \mathrm{G}^{\ddagger}=+9.8 \mathrm{kcal} \cdot \mathrm{mol}^{-1}, \Delta \mathrm{G}=-5.0 \mathrm{kcal} \cdot \mathrm{mol}^{-1}\right)$. Deprotonation of 2 with BTPP can then occur, requiring an activation energy of +22.2 kcal. $\mathrm{mol}^{-1}$ from $3\left(\mathrm{TS}_{2}: \Delta \Delta \mathrm{G}^{*}=+27.2 \mathrm{kcal} . \mathrm{mol}^{-1}\right.$, $\Delta \Delta \mathrm{G}=+2.6 \mathrm{kcal}^{\mathrm{mol}} \mathrm{mo}^{-1}$ ). This step is rate-determining and is key in generating the high-energy, anionic trihydride species 6. Hydride transfer from 6 to $\mathrm{Me}_{3} \mathrm{SiCl}$ provides $\mathbf{5}$, which features the product $\mathrm{Me}_{3} \mathrm{SiH}$ coordinated to dihydride $3,{ }^{27}$ concomitantly with the release of $[\mathrm{BTPPH}] \mathrm{Cl}$ as a salt. This step is 20.8 kcal.mol ${ }^{-1}$ higher in energy than 3 and follows an $\mathrm{S}_{\mathrm{N}} 2$ mechanism at the silicon atom $\left(\mathrm{TS}_{3}: \Delta \Delta \mathrm{G}^{*}=+22.2 \mathrm{kcal} \cdot \mathrm{mol}^{-1}\right.$, $\left.\Delta \Delta \mathrm{G}=+2.7 \mathrm{kcal} \cdot \mathrm{mol}^{-1}\right)$. By releasing the coordinated silane, 3 is regenerated, thereby closing the catalytic cycle $\left(\mathrm{TS}_{4}\right.$ : $\Delta \Delta \mathrm{G}^{\ddagger}=+13.5 \mathrm{kcal}^{\mathrm{mol}} \mathrm{mol}^{-1}, \Delta \Delta \mathrm{G}=-1.9 \mathrm{kcal}^{\mathrm{mol}} \mathrm{mol}^{-1}$ ), with an overall exergonicity of $1.2 \mathrm{kcal}^{\mathrm{mol}} \mathrm{m}^{-1}$. Notably, in agreement with the experiments, the hydride transfer from 3 into $\mathrm{Me}_{3} \mathrm{SiCl}$ has been discarded computationally (see SI Fig. S21). The total energetic span of the catalytic cycle, $27.2 \mathrm{kcal} \mathrm{mol}^{-1}$, is only lightly higher than expected compared to the reaction conditions $\left(18 \mathrm{~h}\right.$ at r.t. under 5 bar of $\left.\mathrm{H}_{2}\right)$ and defined by 2 and the base-assisted activation of coordinated $\mathrm{H}_{2}\left(\mathrm{TS}_{2}\right)$, which is the rate-determining transition state of the reaction.

In summary, hydrogenolysis of some chlorosilanes $\left(\mathrm{Me}_{3} \mathrm{SiH}\right.$, $\mathrm{Et}_{3} \mathrm{SiH}$ and $\mathrm{Me}_{2} \mathrm{SiHCl}$ ) catalyzed by an $\mathrm{Ir}^{\mathrm{III}}$ catalyst in the presence of a sterically hindered guanidine or phosphazene base (MeTBD, BTMG, BTPP) afforded hydrosilanes with moderate to excellent yields and selectivity (up to $98 \%$ ). The reaction proceeds in mild conditions (r.t., 1 to $5 \mathrm{bar}_{2}$ ), with a low catalyst loading ( $1 \mathrm{~mol} \%$ ), without other additional additives, and requires moderate reaction times $(18 \mathrm{~h})$. The active species in the hydride transfer would involve the anionic iridium trihydride complex $\left[\operatorname{Ir}\left({ }^{t}{ }^{\mathrm{Bu}} \mathrm{POCOP}\right) \mathrm{H}_{3}{ }^{-}\right.$], formed by the deprotonation of the $\mathrm{H}_{2}$ complex $\left[\operatorname{Ir}\left({ }^{t \mathrm{Bu} P O C O P}\right) \mathrm{H}_{2}\left(\mathrm{H}_{2}\right)\right]$ with a strong base. This complex exhibits an outstanding hydridic character, able to reduce a chlorosilane to a hydrosilane, without the need for a 
pre-activation of the $\mathrm{Si}-\mathrm{Cl}$ bond. Future works will concern the development of earth-abundant metal or transition metal-free catalysts to replace the noble metal complex.

\section{ASSOCIATED CONTENT}

Supporting Information. This material is available free of charge via the Internet at http://pubs.acs.org.

Detailed descriptions of experimental methods; procedures for the catalytic reduction of the chlorosilanes; stoichiometric reactions with complexes 1-4; and computational details. (PDF)

Coordinates for all computed structures (XYZ File)

\section{AUTHOR INFORMATION}

\section{Corresponding Author}

*Email: thibault.cantat@cea.fr

\section{Author Contributions}

The manuscript was written through contributions of all authors. All authors have given approval to the final version of the manuscript.

\section{Funding Sources}

Financial support was provided by CEA, CNRS, the University Paris-Saclay, and the European Research Council (ERC Consolidator Grant Agreement no. 818260).

Notes

The authors declare no competing financial interest.

\section{ACKNOWLEDGMENTS}

For support of this work, we acknowledge CEA, CNRS, the University Paris-Saclay, CINES (HPC Computing time on Occigen, grant no. A0080806494). T.C. thanks the Fondation Louis D.-Institut de France for its major support.

\section{REFERENCES}

(1) Marciniec, B. Functionalisation and Cross-Linking of Organosilicon Polymers. In Hydrosilylation, Advances in Silicon Science, Springer, 2009, pp 159-189.

(2) Rösch, L.; John, P.; Reitmeier, R. Silicon Compounds, Organic. In Ullmann's Encyclopedia of Industrial Chemistry, Wiley, 2012, pp 664-669.

(3) Aizpurua, M.; Palomo, C. Reagents and Synthetic Methods; 43. A New Practical Preparation of Trimethylsilyl Trifluoromethanesulfonate. Synthesis, 1985, 2, 206-207.

(4) Cheng, C.; Hartwig, J. F. Catalytic Silylation of Unactivated C-H Bonds. Chem. Rev. 2015, 115, 8946-8975.

(5) Li, H.; Misal Castro, L. C.; Zheng, J.; Roisnel, T.; Dorcet, V.; Sortais, J.-B.; Darcel, C. Selective Reduction of Esters to Aldehydes under the Catalysis of Well-Defined NHC-Iron Complexes. Angew. Chem. Int. Ed. 2013, 52 (31), 8045-8049.

(6) (a) Hosokawa, S.; Toya, M.; Noda, A.; Morita, M.; Ogawa, T.; Motoyama, Y. Catalytic Silane-Reduction of Carboxylic Esters and Lactones: Selective Synthetic Methods to Aldehydes, Lactols, and Ethers via Silyl Acetal Intermediates. ChemistrySelect 2018, 3 (11), 2958-2961.; (b) Das, S.; Addis, D.; Junge, K.; Beller, M. Zinc-Catalyzed Chemoselective Reduction of Tertiary and Secondary Amides to Amines. Chem. Eur. J. 2011, 17 (43), 12186-12192.; (c) Pesti, J.; Larson, G. L. Tetramethyldisiloxane: A Practical Organosilane Reducing Agent. Org. Process Res. Dev. 2016, 20 (7), 1164-1181.

(7) Chauvier, C.; Cantat, T. A Viewpoint on Chemical Reductions of Carbon-Oxygen Bonds in Renewable Feedstocks Including $\mathrm{CO}_{2}$ and Biomass. ACS Catal. 2017, 7, 2107-2115.

(8) (a) Monsigny, L.; Feghali, E.; Berthet, J.-C.; Cantat, T. Efficient Reductive Depolymerization of Hardwood and Softwood Lignins with Brookhart's Iridium(III) Catalyst and Hydrosilanes. Green
Chem. 2018, 20 (9), 1981-1986.; (b) Monsigny, L.; Berthet, J.-C.; Cantat, T. Depolymerization of Waste Plastics to Monomers and Chemicals Using a Hydrosilylation Strategy Facilitated by Brookhart's Iridium(III) Catalyst. ACS Sustain. Chem. Eng. 2018, 6 (8), 10481-10488.; (c) Riduan, S. N.; Zhang, Y.; Ying, J. Y. Conversion of carbon dioxide into methanol with silanes over N-heterocyclic carbene catalysts. Angew. Chem. Int. Ed., 2009, 48, 3322.; For reviews see : (d) Schutyser, W.; Renders, T.; Van den Bosch, S.; Koelewijn, S. F.; Beckham, G. T.; Sels B. F. Chemicals from lignin: an interplay of lignocellulose fractionation, depolymerisation, and upgrading. Chem. Soc. Rev., 2018, 47, 852.; (e) Payne, J.; McKeown, P.; Jones. M. D. A Circular Economy Approach to Plastic Waste. Polymer Degradation and Stability, 2019, 165, 170-181.; (f) O’Brien, C. J.; Tellez, J. L.; Nixon, Z. S.; Kang, L. J.; Carter, A. L.; Kunkel, S. R.; Przeworski, K. C.; Chass, G. A. Recycling the Waste: The Development of a Catalytic Wittig Reaction. Angew. Chem. Int. Ed. 2009, 48, 6836-6839.

(9) (a) Kalchauer, W.; Pachaly, B. Müller-Rochow Synthesis: The Direct Process to Methylchlorosilanes. In Handbook of Heterogeneous Catalysis, Wiley, 2008, 12, 2635-2647.; (b) Simmler, W. Silicon Compounds, Inorganic. In Ullmann's Encyclopedia of Industrial Chemistry, Wiley, 2007, pp 616-617.

(10) (a) Di Giorgio, P. A.; Strong, W. A.; Sommer, L. H.; Whitmore, F. C. Preparation of Triethylchlorosilane from Ethyl Orthosilicate. J. Am. Chem. Soc., 1946, 68, 1380.; (b) Bailey, D. L.; Sommer, L. H.; Whitmore, F. C. Some Reactions of Trialkylaminosilanes. J. Am. Chem. Soc., 1948, 70, 435-436.; (c) Masaoka, S.; Bannoa, T.; Ishikawa, $\mathrm{M}$. The synthesis of chlorosilanes from alkoxysilanes, silanols, and hydrosilanes with bulky substituents. J. Organomet. Chem., 2006, 691, 174-181.; (d) Roberts, J. M.; Eldred, D. V.; Katsoulis, D. E. Synthesis of $\mathrm{SiCl}_{4}$ from Gaseous $\mathrm{HCl}$ and $\mathrm{Si}(\mathrm{OMe})_{4}$. Reaction Development and Kinetic Studies. Ind. Eng. Chem. Res., 2016, 55, 1813-1818.

(11) (a) Finholt, A. E.; Bond, A. C.; Wilzbach K. E.; Schlesinger, H. I. The Preparation and Some Properties of Hydrides of Elements of the Fourth Group of the Periodic System and of their Organic Derivatives. J. Am. Chem. Soc., 1947, 69, 2692-2696.; (b) Ito, M.; Itazaki, M.; Abe, T.; Nakazawa, H. Hydrogenation of Chlorosilanes by $\mathrm{NaBH}_{4}$ Chem. Lett., 2016, 45, 1434-1436.

(12) Cottrell, T. L. In The Strengths of Chemical Bonds, 2d ed., Butterworth, London, 1958

(13) (a) Tsushima, D.; Igarashi, M.; Sato, K.; Shimada, S. Ir-catalyzed Hydrogenolysis Reaction of Silyl Triflates and Halides with $\mathrm{H}_{2}$. Chem. Lett. 2017, 46, 1532-1534.; (b) Beppu, T.; Sakamoto, K.; Nakajima, Y.; Matsumoto, K.; Sato, K.; Shimada, S. Hydrosilane synthesis via catalytic hydrogenolysis of halosilanes using a metal-ligand bifunctional iridium catalyst. J. Org. Chem., 2018, 869, 75-80.

(14) Glüer, A.; Schweizer, J. I.; Karaca, U. S.; Würtele, C.; Diefenbach, M.; Holthausen, M. C.; Schneider, S. Hydrosilane Synthesis by Catalytic Hydrogenolysis of Chlorosilanes and Silyl Triflates. Inorg. Chem., 2018, 57, 13822-13828.

(15) (a) Clarke, Z. E.; Maragh, P. T.; Dasgupta, T. P.; Gusev, D. G.; Lough, A. J.; Abdur-Rashid, K. A Family of Active Iridium Catalysts for Transfer Hydrogenation of Ketones. Organometallics, 2006, 25, 4113-4117.; (b) Tanaka, R.; Yamashita, M.; Nozaki, K. Catalytic Hydrogenation of Carbon Dioxide Using Ir(III)-Pincer Complexes. $J$. Am. Chem. Soc., 2009, 131, 14168-14169.

(16) Park, S.; Brookhart, M. Hydrosilylation of Carbonyl-Containing Substrates Catalyzed by an Electrophilic $\eta^{1}$-Silane Iridium(III) Complex. Organometallics, 2010, 29, 6057-6064.

(17) Göttker-Schnetmann, I.; White, P.; Brookhart M. Iridium Bis(phosphinite) $p$-XPCP Pincer Complexes: Highly Active Catalysts for the Transfer Dehydrogenation of Alkanes. J. Am. Chem. Soc., 2004, 126, 1804-1811. [Ir $\left.\left.{ }^{\mathrm{tBu} P O C O P}\right) \mathrm{H}_{2}\right](3)$ was screened for the catalytic hydrogenolysis of a 1:1 mixture of $\mathrm{Me}_{2} \mathrm{SiOTf}_{2}$ and $\mathrm{Me}_{2} \mathrm{SiCl}_{2}$ in the SI of ref. 14.

(18) (a) Pratt, R. C.; Lohmeijer, B. G. G.; Long, D. A.; Waymouth, R. M.; Hedrick, J. L. Triazabicyclodecene: a simple bifunctional organocatalyst for acyl transfer and ring-opening polymerization of cyclic esters. J. Am. Chem. Soc. 2006, 128, 4556-4557.; (b) Kiesewetter, M. K.; Scholten, M. D.; Kirn, N.; Weber, R. L.; Hedrick, J. L.; Waymouth, R. M. Cyclic Guanidine Organic Catalysts: What Is Magic About Triazabicyclodecene? J. Org. Chem. 2009, 74, 9490- 
9496.; (c) Mutlu, H.; Ruiz, J.; Solledera, S. C.; Meier, M. A. R. TBD catalysis with dimethyl carbonate: a fruitful and sustainable alliance. Green Chem., 2012, 14, 1728-1735.; (d) von Wolff, N.; Lefèvre, G.; Berthet, J. C.; Thuéry, P.; Cantat, T. Implications of $\mathrm{CO}_{2}$ Activation by Frustrated Lewis Pairs in the Catalytic Hydroboration of $\mathrm{CO}_{2}$ : A View Using N/Si ${ }^{+}$Frustrated Lewis Pairs. ACS Catal. 2016, 6, 4526-4535. (e) Kondoh, A.; Aoki, T.; Terada, M. Organocatalytic Arylation of $\alpha-$ Ketoesters Based on Umpolung Strategy: Phosphazene-Catalyzed $\mathrm{S}_{\mathrm{N}} \mathrm{Ar}$ Reaction Utilizing [1,2]-Phospha-Brook Rearrangement. Chem. Eur. J. 2018, 24, $13110-13113$.

(19) Lv, Y.; Yan, H.; Yang, B.; Wu, C.; Zhang, X.; Wang, X. Bipolar membrane electrodialysis for the recycling of ammonium chloride wastewater: Membrane selection and process optimization. $J$. Chem. Eng. Res. Design, 2018, 138, 105-115.

(20) See for pKa value: (a) Kaljurand, I.; Kütt, A.; Sooväli, L.; Rodima, T.; Mäemets, V.; Leito, I.; Koppel, I. A. Extension of the SelfConsistent Spectrophotometric Basicity Scale in Acetonitrile to a Full Span of $28 \mathrm{p} K_{\mathrm{a}}$ Units: Unification of Different Basicity Scales. J. Org. Chem., 2005, 70, 1019-1028.; (b) Zall, C. M.; Linehan, J. C.; Appel, A. M. A Molecular Copper Catalyst for Hydrogenation of $\mathrm{CO}_{2}$ to Formate. ACS Catal., 2015, 5, 5301-5305.

See for N parameter (Mayr scale): (c) Ammer, J.; Baidya, M.; Kobayashi, S.; Mayr, H. Nucleophilic reactivities of tertiary alkylamines. J. Phys. Org. Chem., 2010, 23, 1029-1035.; (d) Baidya, M.; Mayr, H. Nucleophilicities and carbon basicities of DBU and DBN. Chem. Commun., 2008, 15, 1792-1794.; (e) Maji, B.; Stephenson, D.S.; Mayr, H. Guanidines: Highly Nucleophilic Organocatalysts. ChemCatChem, 2012, 4, 993-999.
(21) Lee, R.; Lim, X.; Chen, T.; Tan, G. K.; Tan, C.-H.; Huang, K.-W. Selective formation of bicyclic guanidinium chloride complexes: implication of the bifunctionality of guanidines. Tetrahedron Lett. 2009, 50, 1560-1562.

(22) Herzog, U.; Roewer, G. Base catalysed hydrogenation of methylbromooligosilanes with trialkylstannanes, identification of the first methylbromohydrogenoligosilanes. J. Organomet. Chem., 1997, $527,117-124$.

(23) (a) Makhmutov, F. A.; Mishkin, R. N.; Shebarshinova, M. G. Process for preparation of methylsilanes by reduction of silyl chlorides with lithium aluminum hydride in alkylaromatic solvent, RU2266293, 2005.; (b) Selective synthesis of $\mathrm{Me}_{2} \mathrm{SiHCl}$ from $\mathrm{Me}_{2} \mathrm{SiCl}_{2}$ involves the combination of $\mathrm{MgH}_{2}$ and $\mathrm{AlCl}_{3}$ : Dröse, J.; Knott, W.; Wolfgram, D. Verfahren zur Herstellung von Dimethylmonochlorsilan, EP0878476A1, 1998.

(24) Göttker-Schnetmann, I.; White, P. S.; Brookhart, M. Synthesis and Properties of Iridium Bis(phosphinite) Pincer Complexes ( $p$ XPCP $) \operatorname{IrH} H_{2}, \quad(p-\mathrm{XPCP}) \operatorname{Ir}(\mathrm{CO}), \quad(p-\mathrm{XPCP}) \operatorname{Ir}(\mathrm{H})(\operatorname{aryl}), \quad$ and $\quad\{(p-$ XPCP)Ir $\}_{2}\left\{\mu-\mathrm{N}_{2}\right\}$ and Their Relevance in Alkane Transfer Dehydrogenation. Organometallics, 2004, 23, 1766-1776.

(25) Although $\left[\left({ }^{(\mathrm{Bu} u} \mathrm{POCOP}\right) \mathrm{IrH}_{3}\right]\left[{ }^{i \mathrm{Pr}} \mathrm{VBH}\right]$ is not stable in dichloromethane and slowly transforms into [( $\left.\left.{ }^{\mathrm{B} u} \mathrm{POCOP}\right) \mathrm{IrHCl}\right]$, the stoichiometric reaction between $\left[\left({ }^{\mathrm{tBu}} \mathrm{POCOP}\right) \mathrm{IrH}_{3}\right]\left[{ }^{\mathrm{Pr}} \mathrm{VBH}\right]$ and $\mathrm{Me}_{3} \mathrm{SiCl}$ yields $\mathrm{Me}_{3} \mathrm{SiH}$ (see SI, Fig. S19/S20).

(26) Metsänen, T. T.; Hrobarik, P.; Klare, H. F. T.; Kaupp, M.; Oestreich, M. Insight into the Mechanism of Carbonyl Hydrosilylation Catalyzed by Brookhart's Cationic Iridium(III) Pincer Complex. J. Am. Chem. Soc., 2014, 136, 6912-6915.

(27) For a detailed structural analysis of the nature of $\left[\operatorname{Ir}\left({ }^{t \mathrm{Bu}-}\right.\right.$ POCOP $) \mathrm{H}_{2}\left(\mathrm{HSiEt}_{3}\right)$ ] similar to $\mathbf{5}$, see ref 25 . 